\title{
An hrcU-Homologous Gene Mutant of Xanthomonas campestris pv. glycines 8ra That Lost Pathogenicity on the Host Plant but Was Able to Elicit the Hypersensitive Response on Nonhosts
}

\author{
Changsik Oh, ${ }^{1}$ Sunggi Heu, ${ }^{2}$ Jae-Yong Yoo, ${ }^{1}$ and Yongsup Cho ${ }^{1}$ \\ ${ }^{1}$ Department of Agricultural Biology, College of Agriculture and Life Sciences, Seoul National University, \\ Suwon, Korea; ${ }^{2}$ Division of Plant Pathology, National Institute of Agricultural Science and Technology, \\ Suwon, Korea \\ Accepted 6 April 1999.
}

\begin{abstract}
Transposon mutagenesis was used to isolate nonpathogenic mutants of Xanthomonas campestris pv. glycines 8ra, which causes bacterial pustule disease in soybean. A 6.1kb DNA region in which a mutation gave loss of pathogenicity was isolated and found to carry six open reading frames (ORFs). Four ORFs had homology with hrcU, hrcV, hrcR, and hrcS genes of Ralstonia solanacearum and $X$. campestris pv. vesicatoria. One nonpathogenic mutant, $X$. campestris pv. glycines H80, lost pathogenicity on soybean but was able to elicit the hypersensitive response (HR) on nonhost pepper and tomato plants. This mutant still multiplied as well as the wild type in the leaves or cotyledons of soybean. Although the DNA and amino acid sequences showed high homology with known hrp genes, the $h r c U$-homolog ORF is not required for HR induction on nonhost plants, pepper and tomato, or for the multiplication of bacteria in the host plant. This gene was only required for the pathogenic symptoms of $X$. campestris pv. glycines 8ra on soybean.
\end{abstract}

Additional keywords: Tn $\Omega \mathrm{Km}$, type III secretion systems, virulence factors.

The ability of bacteria to elicit pathogenicity in susceptible host plants and the hypersensitive response (HR) in nonhost plants is controlled by hrp genes (Alfano and Collmer 1996). In most cases, hrp genes are organized in a gene cluster spanning 23 to $40 \mathrm{~kb}$ of DNA (Bonas 1994; Alfano and Collmer 1997). hrp genes are divided into three groups according to function: (i) gene regulation; (ii) elicitor production; and (iii) type III secretion system. Sequence comparison of hrp genes that encode secretion systems established a subset of genes that are broadly conserved among animal and plant pathogens, and, therefore, they were recently renamed as hrc (hyper-

Corresponding author: S. Heu; Current address: Division of Molecular Genetics, National Institute of Agricultural Science and Technology, Suwon, Korea; Telephone: 331-290-0341; Fax: 331-290-0392; E-mail: heu@niast.go.kr sensitive response and conserved; Bogdanove et al. 1996). hrc genes are considered to encode core components of the protein secretion pathway. In phytopathogenic bacteria, this system controls the secretion of several proteinaceous elicitors of the HR such as harpins (Wei et al. 1992; He et al. 1993; Arlat et al. 1994) and avr gene products (Leach and White 1996). Because of the functions of hrp genes mentioned above, $h r p$ or $h r c$ mutants lose pathogenicity on susceptible hosts and do not induce an HR on resistant host plants and/or nonhost plants.

Xanthomonas campestris pv. glycines 8ra causes bacterial pustule disease on susceptible soybean cultivars. Hwang et al. (1992) isolated two pathogenicity-related genes, ORF1 and ORF2, from $X$. campestris pv. glycines that are homologous to hrpC3, hrpD1, and hrpD2 of X. campestris pv. vesicatoria (Bonas 1994). Besides these, no other hrp genes or pathogenicity genes have been reported from this pathogen. Here, we present the isolation and characterization of pathogenicityrelated genes from $X$. campestris pv. glycines 8ra that have homology to known hrp genes.

To isolate the pathogenicity-related genes, $X$. campestris $\mathrm{pv}$. glycines 8ra was mutagenized with $\mathrm{Tn} \Omega \mathrm{Km}$ (Felley et al. 1989) and tested on soybean cultivars Paldal and Pella for the loss of pathogenicity. One nonpathogenic mutant of $X$. campestris pv. glycines 8ra (of 2,000 tested) was isolated and named $X$. campestris pv. glycines $\mathrm{H} 80$. The growth rate of $X$. campestris pv. glycines $\mathrm{H} 80$ was not different from that of the wild-type strain in both nutrient broth and the host plant soybean cv. Paldal (Fig. 1). Though the mutant strain was not able to cause disease on the host plant, it was still able to cause the HR on the nonhost plants pepper (Capsicum annuum L. 'Chogwang') and tomato (Lycopersicon esculentum Mill. 'Seogwang'), as was the wild type (Fig. 2). Both mutant and wild-type strains were not able to induce the HR on the nonhost plant tobacco (Nicotiana tabacum cv. Samsun). The mutant could not be distinguished from the wild type with several different physiological and biochemical tests, and cellulolytic and proteolytic activities of the mutant were similar to those of the wild type. A Southern hybridization 


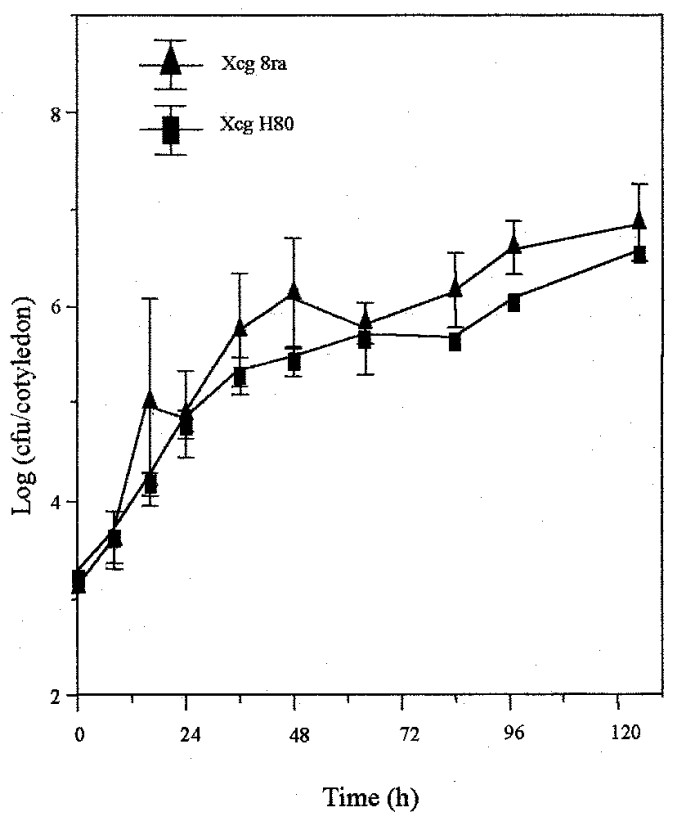

Fig. 1. Growth patterns of Xanthomonas campestris pv. glycines 8ra and H80 in cotyletons of soybean. Cotyledons were inoculated with $10^{4}$ $\mathrm{CFU} / \mathrm{ml}$ of each bacterial strain. Multiplication assays were performed by grinding each cotyledon after measuring the weight in $1 \mathrm{ml}$ of phosphate buffer $(10 \mathrm{mM}, \mathrm{pH} 7.5)$, followed by serial dilution and plating of the samples onto agar plates with appropriate antibiotics. The values reported are the means of three replicates. Error bars indicate the standard deviation. experiment with $\mathrm{Tn} \Omega \mathrm{Km}$ as a probe showed that only a single copy of $\operatorname{Tn} \Omega \mathrm{Km}$ was inserted in the genomic DNA of the mutant (data not shown).

To identify gene(s) responsible for the loss of pathogenicity, isolated total DNA of the mutant was digested with EcoRI and religated to produce the plasmid with the characteristics of $\mathrm{Tn} \Omega \mathrm{Km}$. The ligated plasmid was transformed into Escherichia coli DH5 $\alpha$ and kanamycin-resistant colonies were selected. Selected kanamycin-resistant colonies contained a plasmid carrying a 6.1-kb DNA fragment from $X$. campestris pv. glycines 8ra flanked with $\mathrm{Tn} \Omega \mathrm{Km}$ and this plasmid was named $\mathrm{pH} 80$. In order to isolate wild-type genomic DNA corresponding to this selected region, 3,000 clones from a genomic library of $X$. campestris pv. glycines 8ra were screened by colony hybridization with $\mathrm{pH} 80$ as a probe. Two clones were selected and designated pCS1 and pCS2. Each had about $29 \mathrm{~kb}$ of genomic DNA inserted in the plasmid vector pLAFR3. Restriction enzyme analysis (Fig. 3A) and Southern hybridization experiments showed that the two clones were overlapped in the 6.1-kb EcoRI-EcoRI fragment of pCS2 and the 4.8-kb EcoRI-HindIII fragment of pCS1.

The 6.1-kb EcoRI-EcoRI fragment carrying the DNA region for the loss of pathogenicity of the mutant $X$. campestris pv. glycines $\mathrm{H} 80$ was subcloned into pBluescript II $\mathrm{SK}^{+}$ (Stratagene, La Jolla, CA) to create pCS2E2 and the nucleotide sequence of both strands in the entire fragment was determined (Figs. 3B and 4). Six open reading frames (ORFs) were found to extend from the left-hand EcoRI site to the right-hand EcoRI site (Fig. 3B). The ORFs were predicted to encompass nucleotides 124 to $1,197,1,206$ to $3,128,3,151$ to
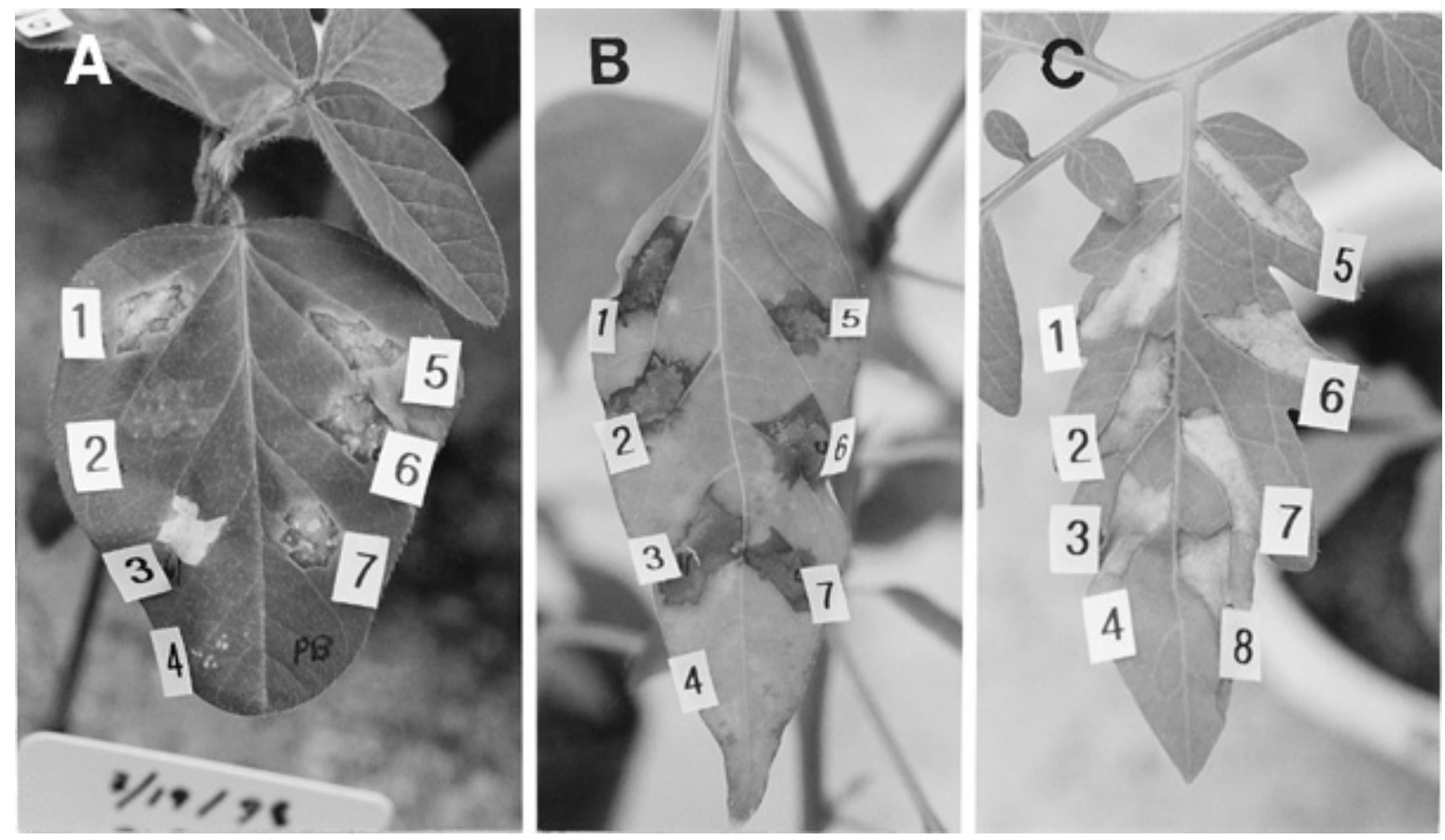

Fig. 2. Responses of different plants to Xanthomonas campestris pv. glycines 8ra and H80. A, Disease symptoms on host plant, soybean (Glycine max L. 'Paldal'). Primary leaves of soybean seedling were inoculated with $10^{8}$ to $5 \times 10^{8} \mathrm{CFU} / \mathrm{ml}$ of indicated bacteria and photographed 3 days after infiltration. Hypersensitive response (HR) on nonhost plants (B) pepper (cv. Chogwang) and (C) tomato (cv. Seogwang ). Fully expanded leaves of these plants were inoculated with $10^{8}$ to $5 \times 10^{8} \mathrm{CFU} / \mathrm{ml}$ of the indicated bacteria and photographed after $24 \mathrm{~h}$. A and B: $1, X$. campestris pv. glycines 8ra; 2 , X. campestris pv. glycines H80; 3, Pseudomonas syringae pv. syringae Pss61; 4, $10 \mathrm{mM}$ phosphate buffer; 5-7, X. campestris pv. glycines H80 (pCS2HBCP). C: 1, X. campestris pv. glycines 8ra; 2, X. campestris pv. glycines H80; 3, P. syringae pv. syringae Pss61; 4, 10 mM phosphate buffer; 5, X. campestris pv. glycines NP1; 6-8, X. campestris pv. glycines $\mathrm{H} 80$ (pCS2HBCP). 
$3,765,3,895$ to $4,809,4,838$ to 5,443 , and 5,448 to 5,708 , and were designated ORF4, ORF5, ORF6, ORF1, ORF2, and ORF3, respectively. It had been reported that the conserved DNA sequence known as a PIP-box (TTCGC-15N-TTCGC) was found upstream of most transcriptional units of the hrp gene cluster isolated from $X$. campestris pv. vesicatoria and Ralstonia solanacearum (Bonas 1994; Fenselau and Bonas 1995). Since PIP-boxes were found upstream of ORF1 and ORF4, these genes appear to form two different transcriptional units. The putative amino acid sequence and ribosomebinding sites of all genes are shown in Figure 4. X. campestris pv. glycines $\mathrm{H} 80$ was determined to have a $3.4-\mathrm{kb} \mathrm{Tn} \Omega \mathrm{Km}$ insertion between 842 and $843 \mathrm{bp}$, which is in the middle of ORF4. The DNA region including ORF1 and ORF2 was the same region reported to carry ORF1 and ORF2 by Hwang et al. (1992). However, the DNA sequencing results with both strands showed some nucleotide sequence differences from those of the reported ORF1 and ORF2. In our DNA sequence, with the DNAsis program (Hitachi Software, Yokohama, Japan), two putative translational starting codons, GTG and ATG, at the 3,895 and 4,003 bases, respectively, were found in the same frame of ORF1. If the putative PIP-box found in the 3,624-bp region is considered, the upstream GTG codon is more reasonable than the first ATG codon, which is reported as the putative translational start codon for ORF1 by Hwang et al. (1992). Also, the termination codon of ORF1 appears from our analysis to be at 4,809 instead of 4,541 nucleotides. Therefore, the predicted ORF1 extends from 543 to $915 \mathrm{nu}-$ cleotides and encodes 304 amino acids. We also interpret our data to support changing the starting codon for ORF 2 from the previously reported ATG at 4,796 bp to a new ATG at 4,838 bp.

In order to determine if the nonpathogenic mutant phenotype could be complemented with this region, the subclone pCS2HBCP carrying the 9.5-kb DNA region from the HindIII site to the $B g l I I$ site in the plasmid vector pCPP30 was constructed (Fig. 3; Deng et al. 1998) and transferred into $X$. campestris pv. glycines H80. The transconjugant carrying the pCS2HBCP regained pathogenicity on soybean plants (Fig. 2) to the wild-type level.

The amino acid sequences of six deduced polypeptides were compared with sequences in GenBank by the BLAST program (Altschul et al. 1990) and the DNAsis program (Hitachi Software). Homologous regions were aligned with the CLUSTAL V program (EMBL Lab, Heidelberg, Germany). The similarities of these proteins with those previously reported are summarized in Table 1. The putative polypeptides of ORF4, ORF5, ORF6, ORF1, ORF2, and ORF3 were similar to HrpN (50.7\% identity/77\% similarity), HrpO (62\% identity/74\% similarity), HpaP (29.4\% identity $/ 57.4 \%$ similarity), HrpQ (31\% identity/60\% similarity), HrpT (81\% identity/91\% similarity), and $\mathrm{HrpU}$ (63\% identity/73\% similarity) of $R$. solanacearum, respectively. In the case of ORF5, the amino acid sequence had the highest identity (87\%) and similarity (94\%) with the amino acid sequence for the $h r p C 2$ gene isolated from $X$. campestris pv. vesicatoria. Since hrpC2 is the only published data from $X$. campestris pv. vesicatoria in this region, it was not possible to compare the sequence of other ORFs with hrp genes isolated from $X$. campestris pv. vesicatoria. In general, these proteins were more similar to those of $R$. solanacearum and $X$. campestris pv. vesicatoria than to those of $P$. syringae pv. syringae and E. amylovora among phytopathogenic bacteria.

The putative ORF4 polypeptide was similar to YscU (34\% identity/61\% similarity) of Yersinia spp., SpaS (29\% identity $60 \%$ similarity) of Salmonella typhimurium, and Spa40 (28\% identity/56\% similarity) of Shigella flexneri. Ysc proteins are involved in the translocation of Yop proteins or virulence factors in Yersinia spp. and Spa proteins are involved in the secretion of invasion antigens to the bacterial surface in Salmonella and Shigella spp. Putative proteins encoded by ORF5, ORF2, and ORF3 were similar to LcrD, YscR, and YscS in Yersinia pestis and InaV, SpaP, and SpaQ in Salmonella typhimurium, respectively. Putative ORF4, ORF1,

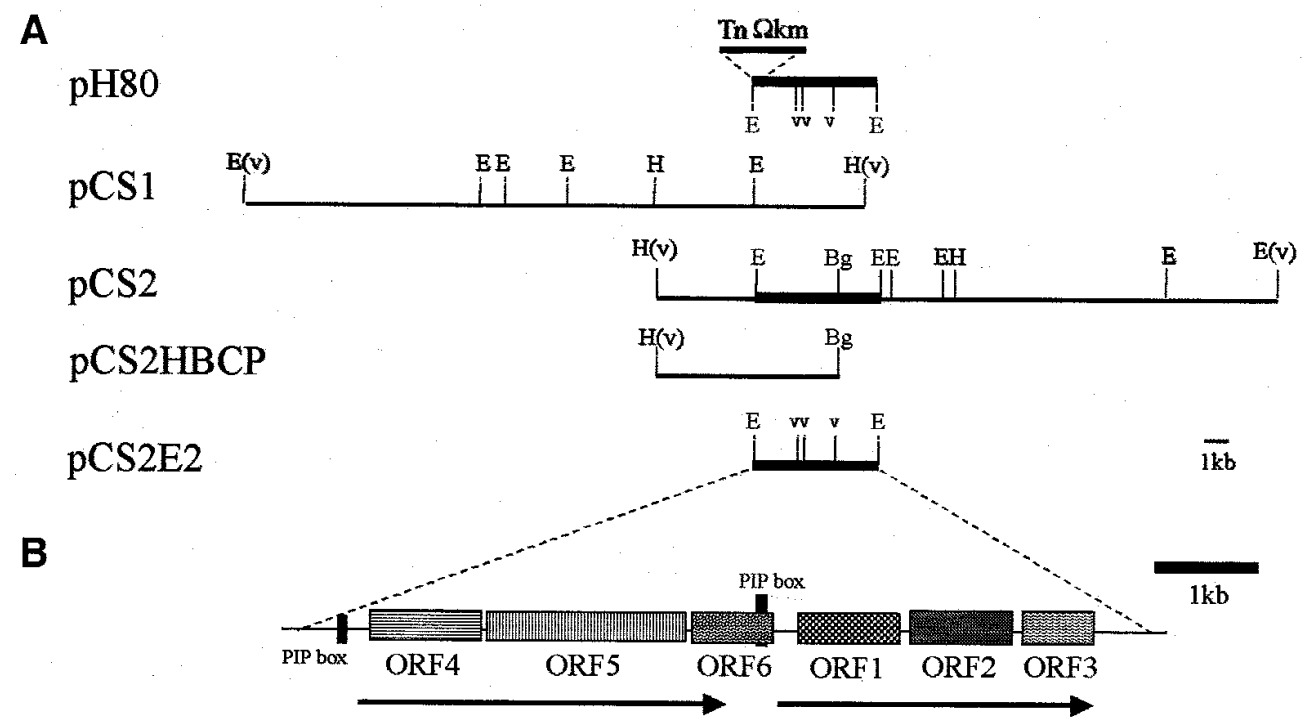

Fig. 3. A, Restriction enzyme maps of pH80, pCS1, pCS2, pCS2HBCP, and pCS2E2. Restriction enzyme site abbreviations: E, EcoRI; H, HindIII; B, BamHI; V, EcoRV; P, PstI; Bg, BglII; (v), an enzyme site on the vector. B, Open reading frames (ORFs) of pCS2E2. ORFs in pCS2E2 are indicated as boxes and arrow boxes. Horizontal arrows indicate transcriptional units. 


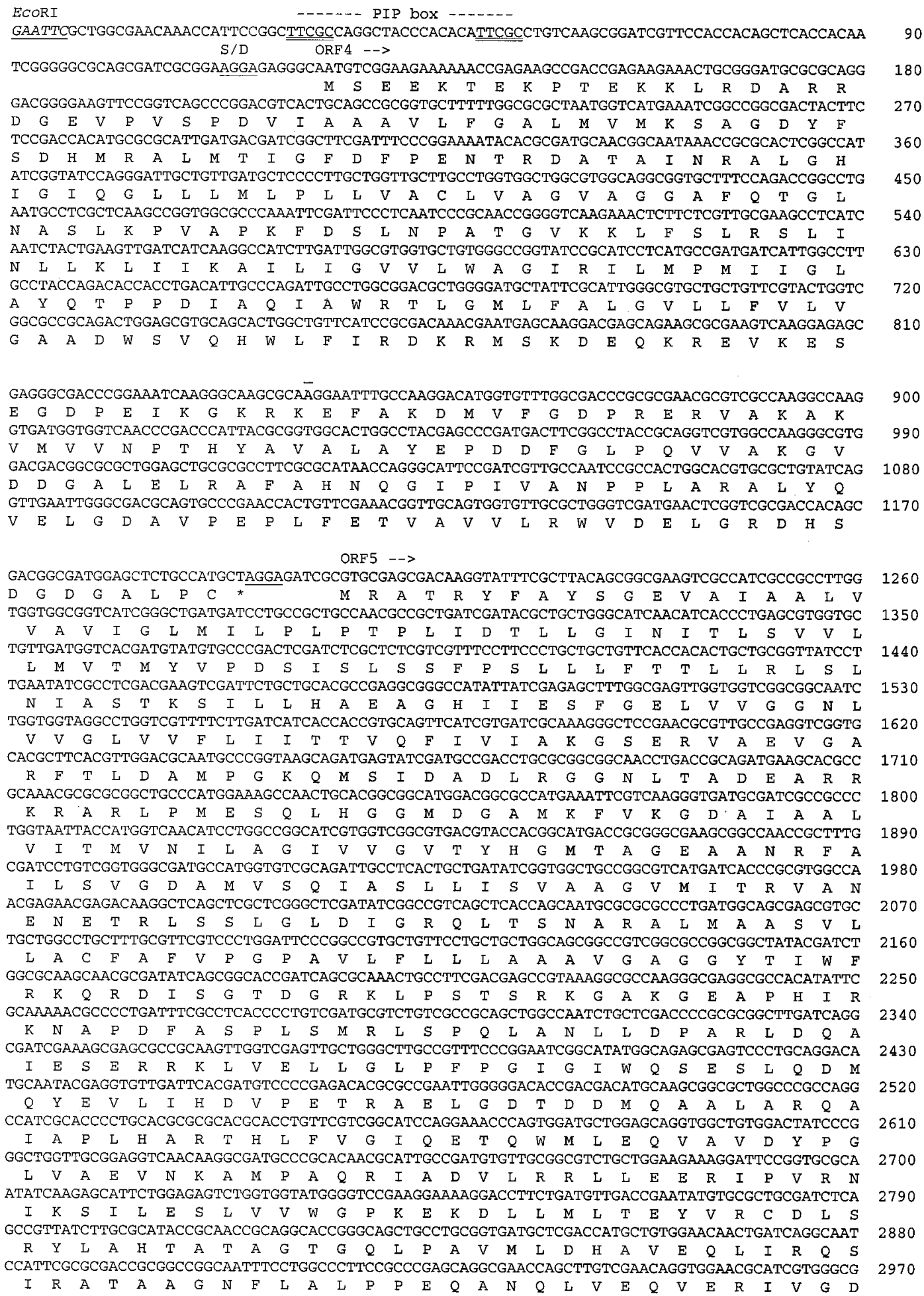

(continued on next page)

Fig. 4. Nucleotide sequence of 6,125-bp EcoRI-EcoRI fragment of pCS2. Dduced amino acid sequence is shown by single-letter codes below. Potential ribosome-binding sites (S/D) preceding six open reading frames (ORFs) are underlined; horizontal arrows indicate orientation of transcription. Vertical arrowhead indicates $\mathrm{Tn} \Omega \mathrm{Km}$ insertion into ORF4. PIP-box (TTCGC-15N -TTCGC) is located upstream of ORF1 and ORF4 and underlined with double line. 
ORF2, and ORF3 proteins had some homology with $\mathrm{HrcU}$, HrcQ, HrcR, and HrcS involved in the type III secretion pathway in Rhizobium fredii. Putative ORF4, ORF5, ORF1, ORF2, and ORF3 proteins also had some homology with the proteins involved in the flagellar biosynthesis, which are FlhB, FlhA, FliY, FliP, and FliQ of Bacillus subtilis, respectively (Table 1).
In this work, $\mathrm{Tn} \Omega \mathrm{Km}$ was used to generate a nonpathogenic mutant, X. campestris pv. glycines H80. This mutant showed no physiological or phenotypic differences from the wild-type strain except in terms of pathogenicity. The mutant strain H80 was not able to cause disease on its host plant soybean. This phenotype is very similar to those of pth (pathogenicity) mu-

Fig. 4. (continued from preceding page)

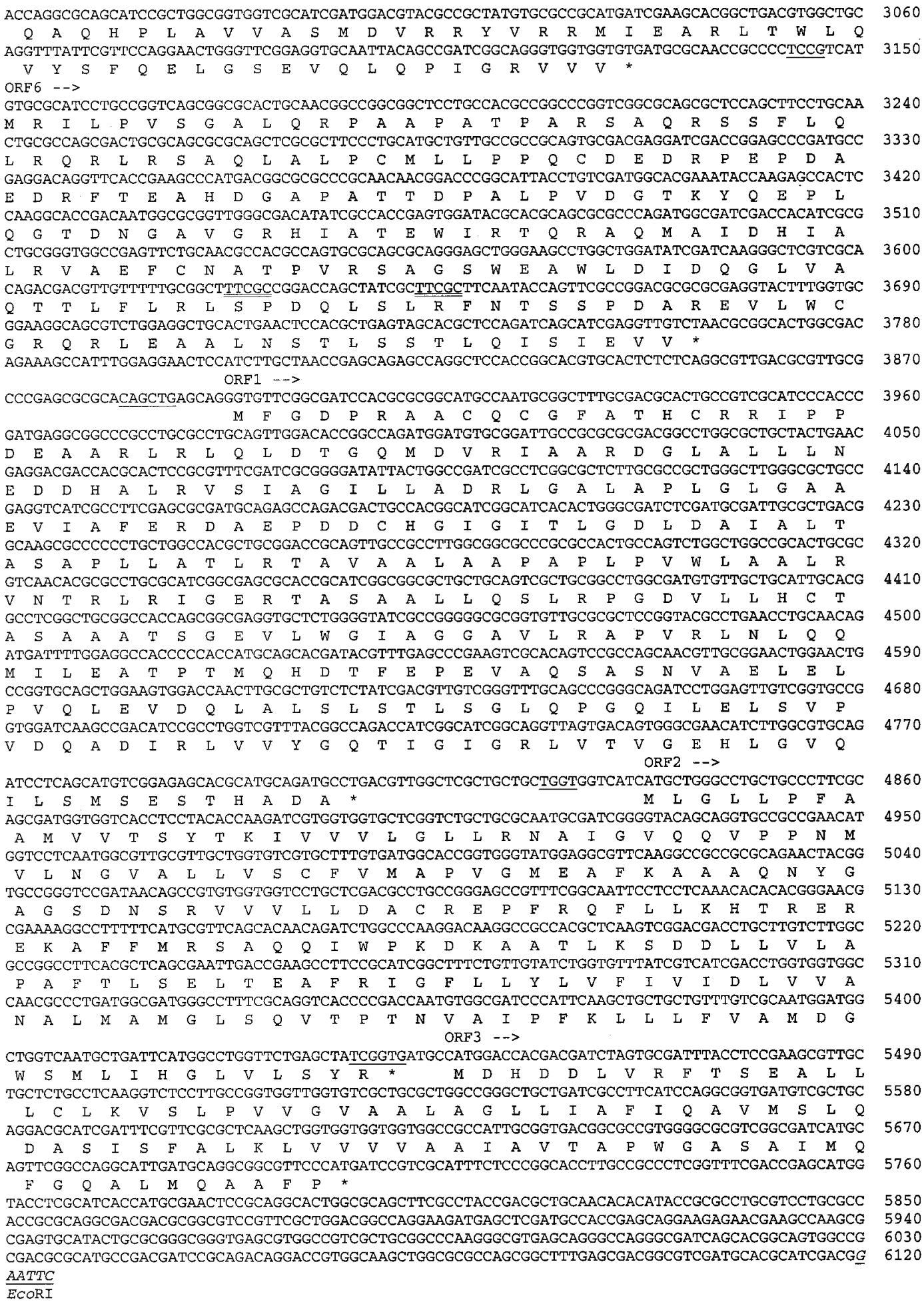


tants of X. campestris pv. malvacearum (Chakrabarty et al. 1997) and $d s p$ (disease specific) mutants of Erwinia amylovora (Bogdanove et al. 1998; Gaudriault et al. 1997). However, the DNA sequence of the mutated region of $X$. campestris pv. glycines 8ra showed a high degree of homology with known hrc genes. The 6.1-kb DNA region carrying the mutation consists of six ORFs, and these ORFs had a homology with $h r p$ or $h r c$ genes isolated from other phytopathogenic bacteria. The organization of isolated ORFs in the cluster looks very similar to that of transcriptional units III and IV of the hrp gene cluster isolated from $R$. solanacearum (Fig. 5). Sequence data showed that the ORF4 has over $50 \%$ homology with $\mathrm{HrcU}$ of $R$. solanacearum. HrcU is involved in the hrpdependent type III secretion systems (Kim et al. 1997; Lidell and Hutcheson 1994). All known hrc $U$ gene mutants have lost pathogenicity on the host plant and were not able to induce the HR on nonhost plants. However, despite the homology with known $h r c U$ gene, the ORF4 mutant of $X$. campestris pv. glycines 8ra lost pathogenicity on the host plant soybean, but was still able to induce the HR on nonhost plants, pepper and tomato (Jones and Fett 1985; Schulte and Bonas 1992). It is known that polar mutation is predominant in $\mathrm{Tn} \Omega \mathrm{Km}$ insertions (Felley et al. 1989). Since ORF4, ORF5, and ORF6 are in one transcriptional unit, it is likely that ORF4, ORF5, and ORF6 genes are all untranscribed due to the insertion of $\mathrm{Tn} \Omega \mathrm{Km}$ in ORF4. This suggests that some genes in this cluster, though they have good homology with known hrp and hrc genes, are involved just in pathogenicity but not in HR induc- tion on nonhost plants. In support of this, the phenotype of another mutant, NP1, of $X$. campestris pv. glycines 8ra that has mutation(s) in ORF1 and/or ORF2 was very similar to those of H80. NP1 was not able to cause disease on its host plant (Hwang et al. 1992). When we tested NP1 on tomato and pepper, it did induce the HR on both plants (Fig. 2).

The mutant H80 was able to multiply as well as the wild type both in liquid culture and in the host plant soybean. Most hrp gene mutants cannot multiply in host plants. However, this $h r c U$-homologous gene mutant, $X$. campestris pv. glycines $\mathrm{H} 80$, was able to grow as well as wild type in the host plant, but it cannot induce disease in that host plant. This suggests that these hrc/hrp-homologous genes in X. campestris pv. glycines 8ra may be required for secretion of virulence factors but not for the induction of HR in nonhost plants. In the animal-pathogenic bacteria, virulence factors such as Yop (Yersinia outermembrane proteins) of Yersinia spp. and Ipa (invasion plasmid antigens) of Shigella flexneri are secreted through the type III secretion pathway. However, in the phytopathogenic bacteria, no virulence factors that are secreted through the hrp-dependent type III secretion system are reported. Cloned genes had a homology with $h r c U$, $h r c V$, $h r c Q$, $h r c R$, and $h r c S$, which are major components of hrpdependent type III secretion systems. Therefore, in X. campestris pv. glycines 8ra, these genes may be components of a secretion system and this secretion system may be involved in the secretion of some virulence factors, like the animalpathogenic bacteria, without affecting bacterial multiplication

Table 1. Homologs of putative polypeptides of Xanthomonas campestris pv. glycines 8ra hrp-homologous genes

\begin{tabular}{|c|c|c|c|c|c|c|}
\hline \multirow[b]{2}{*}{ Category and species } & \multicolumn{6}{|c|}{ Similarity of protein to $X$. campestris pv. glycines 8ra protein } \\
\hline & ORF4 & ORF5 & ORF6 & ORF1 & ORF2 & ORF3 \\
\hline \multicolumn{7}{|l|}{ Pathogenic determinants } \\
\hline X. campestris pv. vesicatoria & & HrpC2 (87/94) & & & & \\
\hline Ralstonia solanacearum & $\operatorname{HrpN}(50.7 / 77)^{\mathrm{a}}$ & $\mathrm{HrpO}(62 / 74)$ & HpaP (29.4/57.4) & HrpQ (31/60) & HrpT (78/89.5) & $\operatorname{HrpU}(63 / 73)$ \\
\hline Pseudomonas syringae pv. syringae & $\operatorname{HrpY}(33 / 63)$ & HrpI (33/53) & & & HrpW $(44 / 69)$ & HrpO (26/64) \\
\hline Erwinia amylovora & $\mathrm{HrcU}(30 / 57)$ & $\operatorname{HrcV}(37 / 59)$ & & & HrcR (40/68) & $\operatorname{HrcS}(34 / 70)$ \\
\hline Yersinia enterocolitica & YscU (34/61) & $\operatorname{LcrD}(43 / 65)$ & & & & \\
\hline Y. pestis & & $\operatorname{LcrD}(42 / 62)$ & & YscQ (25/56) & YscR (50/73.6) & YscS (36/66) \\
\hline Salmonella typhimurium & SpaS $(29 / 60)$ & InaV (43/66) & & & $\operatorname{SpaP}(39 / 69)$ & $\operatorname{SpaQ}(29 / 62)$ \\
\hline S. flexneri & Spa40 $(28 / 56)$ & MxiA (43/69) & & & Spa24 (41/70) & Spa9 $(30 / 60)$ \\
\hline \multicolumn{7}{|l|}{ Flagellar proteins } \\
\hline B. subtilis & FlhB (34/62.5) & FlhA (38/58) & & FliY (18.7/54.6) & FliP (42/68) & FliQ (28/59) \\
\hline Y. enterocolitica & FlhB (31.6/60.5) & FlhA (40/65) & & & & \\
\hline S. typhimurium & FlhB $(34 / 62.5)$ & FllhA $(39 / 63)$ & & & $\mathrm{FliP}(48 / 70)$ & \\
\hline Escherichia coli & & FlhA $(39 / 64)$ & & & FliP (49/75) & FliQ (24/65) \\
\hline R. fredii & $\mathrm{HrcU}(28 / 54.6)$ & & & HrcQ (24/55.6) & $\operatorname{HrcR}(49 / 72)$ & $\operatorname{HrcS}(30 / 69)$ \\
\hline
\end{tabular}

${ }^{a}$ Identity/similarity values are expressed in percentages as estimatied by the CLUSTAL V program (EMBL Lab, Heidelberg, Germany).

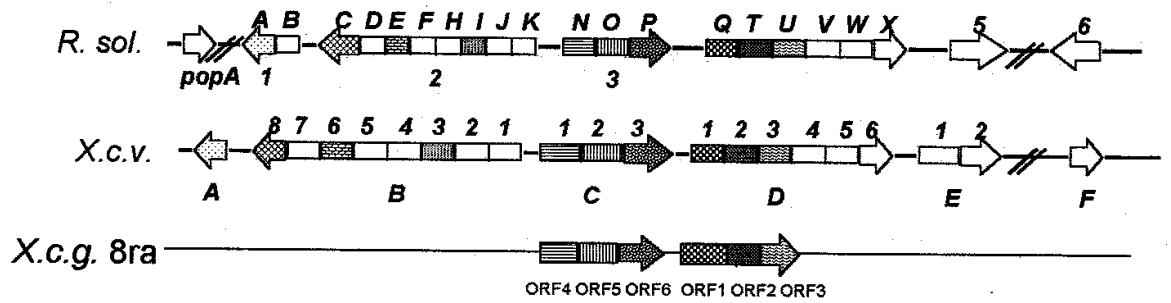

Fig. 5. Genetic organization of hrp-homologous genes from Xanthomonas campestris pv. glycines 8ra and hrp gene cluster of Ralstonia solanacearum and $X$. campestris pv. vesicatoria. Transcription units (horizontal arrows) and relative positions of the genes are presented. Genes with related encoded proteins are represented by the same shape. Maps were drawn according to Van Gijsegem et al. (1995) for R. solanacearum and Fenseleau et al. (1992) for $X$. campestris pv. vesicatoria. Boxes are not drawn to scale. 
(Cornelis 1994). In X. campestris pv. glycines, virulence factors such as auxin and cytokinin, toxin, EPS (exopolysaccharide), protease, and cellulase are reported (Fett and Dunn 1987; Paxton 1972). No differences were observed for the production of EPS and proteolytic and cellulolytic activities between wild-type $X$. campestris pv. glycines 8ra and mutant $X$. campestris pv. glycines $\mathrm{H} 80$. Whether or not the secretion of other virulence factors such as auxin, cytokinin, and toxin is different between wild type and mutant, we don't know yet. Those possibilities are under investigation.

\section{ACKNOWLEDGMENTS}

We thank I. Hwang for the bacterial strain X. campestris pv. glycines NP1 he provided as well as his fruitful comments, and S. H. Choi for technical assistance. We also thank S. Hutcheson for the preparation of this manuscript and the sincere discussion for this paper. This work was supported in part by NON DIRECTED RESEARCH FUND, Korea Research Foundation.

\section{LITERATURE CITED}

Alfano, J. R., and Collmer, A. 1996. Bacterial pathogens in plants: Life up against the wall. Plant Cell 8:1683-1698.

Alfano, J. R., and Collmer, A. 1997. The type III (Hrp) secretion pathway of plant pathogenic bacteria: Trafficking Harpins, Avr proteins, and death. J. Bacteriol. 179:5655-5662.

Altschul, S. F., Fish, W., Miller, W., Myers, E. W., and Lipman, D. J. 1990. Basic local alignment search tool. J. Mol. Biol. 215:403-410.

Arlat, M., Van Gijsegem, F., Huet, J. C., Penollet, J. C., and Boucher, C. A. 1994. PopA1, a protein which induces a hypersensitivity-like response on specific Petunia genotype, is secreted via the Hrp pathway of Pseudomonas solanacearum. EMBO J. 13:543-553.

Bogdanove, A. J., Beer, S. V., Bonas, U., Boucher, C. A., Collmer, A., Coplin, D. L., Cornelis, G. R., Huang, H., Hutcheson, S. W., Panopoulos, N. J., and Gijsegem, F. V. 1996. Microcorrespondence; unified nomenclature for broadly conserved hrp genes of phytopathogenic bacteria. Mol. Microbiol. 20:681-683.

Bogdanove, A. J., Kim, J. F., Wei, Z., Kolchinsky, P., Charkowski, A. O., Conlin A. K., Collmer, A., and Beer, A. 1998. Homology and functional similarity of an hrp-linked pathogenicity locus, $d s p \mathrm{EF}$, of Erwinia amylovora and the avirulence locus avrE of Pseudomonas syringae pathovar tomato. Proc. Natl. Acad. Sci. USA 95:1325-1330.

Bonas, U. 1994. hrp genes of phytopathogenic bacteria. Curr. Top. Microbiol. Immunol. 192:79-98.

Chakrabarty, P. K., Duan, Y. P., and Gabriel, D. W. 1997. Cloning and characterization of a member of the Xanthomonas avr/pth gene family that evades all commercially utilized cotton $R$ genes in the United States. Phytopathology 87:1160-1167.

Cornelis, G. R. 1994. Yersinia pathogenicity factors. Curr. Top. Microbiol. Immunol. 192:243-263.

Deng, W., Preston, G., Collmer, A., Chang, C., and Huang, H. 1998. Characterization of the hrpC and hrpRS operons of Pseudomonas syringae pathovars syringae, tomato, and glycinea and analysis of the ability of $h r p \mathrm{~F}, h r p \mathrm{G}, h r c \mathrm{C}, h r p \mathrm{~T}$, and $h r p \mathrm{~V}$ mutants to elicit the hypersensitive response and disease in plants. J. Bacteriol. 180:45234531.

Felley, R., Krisch, H. M., Prentki, P., and Frey, J. 1989. Omegon-Km: A transposable element designed for in vivo insertional mutagenesis and cloning of genes in Gram-negative bacteria. Gene 76:215-226.

Fenselau, S., Balbo, I., and Bonas, U. 1992. Determinants of pathogenicity in Xanthomonas campestris pv. vesicatoria are related to proteins involved in secretion in bacterial pathogens of animals. Mol. Plant-Microbe Interact. 5:390-396.

Fenselau, S., and Bonas, U. 1995. Sequence and expression analysis of the hrpB pathogenicity operon of Xanthomonas campestris pv. vesicatoria which encodes eight proteins with similarity to components of the Hrp, Ysc, Spa, and Fli secretion systems. Mol. Plant-Microbe Interact. 8:845-854.

Fett, W. F., and Dunn, M. F. 1987. Auxin production by plantpathogenic pseudomonads and xanthomonads. Appl. Environ. Microbiol. 53:1839-1845.

Gaudriault, S., Malandrin, L., Paulin, J. P., and Barny, M. A. 1997. DspA, an essential pathogenicity factor of Erwinia amylovora showing homology with AvrE of Pseudomonas syringae, is secreted via the Hrp secretion pathway in a DspB-dependent way. Mol. Microbiol. 26: 1057-1069.

He, S. Y., Huang, H. C., and Collmer, A. 1993. Pseudomonas syringae pv. syringae HarpinPss: A protein that is secreted via the Hrp pathway and elicits the hypersensitive response in plants. Cell 73:1255-1266.

Hwang, I., Lim, S. M., and Shaw, P. D. 1992. Cloning and characterization of pathogenicity genes from Xanthomonas campestris pv. glycines. J. Bacteriol. 174:1923-1931.

Jones, S. B., and Fett, W. F. 1985. Fate of Xanthomonas campestris infiltrated into soybean leaves: An ultrastructural study. Phytopathology 75:733-741.

Kim, J. F., Wei, Z., and Beer, S. V. 1997. The hrpA and hrpC operons of Erwinia amylovora encode components of a type III pathway that secretes harpin. J. Bacteriol. 179:1690-1697.

Leach, J., and White, F. F. 1996. Bacterial avirulence genes. Annu. Rev. Phytopathol. 34:153-179.

Lidell, M. C., and Hutcheson, S. W. 1994. Characterization of the hrpJ and hrpU operons of Pseudomonas syringae pv. syringae Pss61: Similarity with components of enteric bacteria involved in flagellar biogenesis and demonstration of their role in Harpin $_{\text {Pss }}$ secretion. Mol. Plant-Microbe Interact. 7:488-497.

Parsot, C. 1994. Shigella flexneri: Genetics of entry and intercellular dissemination in epithelial cells. Curr. Top. Microbiol. Immunol. 192: 217-241.

Paxton, J. D. 1972. Toxin production by Xanthomonas phaseoli var. sojensis. Page 377 in: Phytotoxins in Plant Diseases, Proceeding of the NATO Advanced Study Institute, Pugnochiuso, Italy, June 1970. R. K. S. Wood, A. Ballio, and A. Graniti, eds. Academic Press, London.

Schulte, R., and Bonas, U. 1992. Expression of the Xanthomonas campestris pv. vesicatoria hrp gene cluster, which determines pathogenicity and hypersensitivity on pepper and tomato, is plant inducible. J. Bacteriol. 174:815-823.

Srivastava, S. L., and Bias, B. S. 1986. Involvement of pecteolytic and cellulolytic enzymes in bacterial leaf pustule of soybean. Farm Sci. J. $1: 82-84$.

Van Gijsegem, F., Gough, C., Zischek, C., Niqueux, E., Arlat, M., Genin, S., Barberis, P., German, S., Castello, P., and Boucher, C. 1995. The hrp gene locus of Pseudomonas solanacearum, which controls the production of a type III secretion system, encodes eight proteins related to components of the bacterial flagellar biogenesis complex. Mol. Microbiol. 15:1095-1114.

Wei, Z., Laby, R. J., Zumoff, C. H., Bauer, D. W., He, S. Y., Collmer, A., and Beer, S. V. 1992. Harpin, elicitor of the hypersensitive response produced by the plant pathogen Erwinia amylovora. Science 257:8588. 